in vivo $34: 2209-2215(2020)$

doi:10.21873/invivo.12031

Review

\title{
Prognostic Value of CD63 Expression in Solid Tumors: A Meta-analysis of the Literature
}

\author{
HYUN MIN KOH ${ }^{1}$, BO GUN JANG ${ }^{2,3}$ and DONG CHUL KIM ${ }^{4,5,6}$ \\ ${ }^{1}$ Department of Pathology, Gyeongsang National University Changwon Hospital, Changwon, Republic of Korea; \\ ${ }^{2}$ Department of Pathology, Jeju National University School of Medicine, Jeju, Republic of Korea; \\ ${ }^{3}$ Department of Pathology, Jeju National University Hospital, Jeju, Republic of Korea; \\ ${ }^{4}$ Department of Pathology, Gyeongsang National University School of Medicine, Jinju, Republic of Korea; \\ ${ }^{5}$ Department of Pathology, Gyeongsang National University Hospital, Jinju, Republic of Korea; \\ ${ }^{6}$ Gyeongsang Institute of Health Science, Jinju, Republic of Korea
}

\begin{abstract}
Background: CD63 has been described as a key factor in extracellular vesicle production and endosomal cargo sorting, and there have been certain reports suggesting an association between CD63 expression and survival in patients with tumors including gastric, colon and lung cancer. However, the prognostic value of CD63 expression remains contradictory. Hence, we performed this meta-analysis to assess the prognostic value of CD63 expression in solid tumors. Materials and Methods: Eligible studies were collected by searching the PubMed, Embase and Cochrane libraries. The hazard ratio (HR) with $95 \%$ confidence interval (CI) were evaluated to reveal the association between CD63 expression and survival in solid tumors. Results: Five studies with a total of 1,454 patients were included. The HR evaluating CD63 expression on survival was 1.34 (95\%CI=0.92-1.97, $p=0.129)$. In subgroup analysis, the HRs of lung cancer and other tumors were 0.50 (95\% $C I=0.32-0.77, p=0.002)$ and $2.16(95 \% C I=1.93-2.42$, $p<0.001)$ respectively. CD63 expression was significantly associated with poor disease-specific survival (HR=1.69, 95\% CI=1.15-2.49, $p=0.008)$, but not with disease-free survival and overall survival. Also, there was a significant association between CD63 expression with poor survival in the group of sample size more than 150 patients $(H R=2.15$,
\end{abstract}

This article is freely accessible online.

Correspondence to: Dong Chul Kim, MD, Ph.D., Department of Pathology, Gyeongsang National University School of Medicine, 79 Gangnam-ro, Jinju 52727, Republic of Korea. Tel: +82 552143150, Fax:+82 552143174, e-mail: kdcjes@gmail.com

Key Words: CD63, meta-analysis, prognosis, solid tumors.
95\% CI=2.92-2.41, $<<0.001)$, but not in the group of sample size with fewer than 150 patients. Conclusion: This metaanalysis suggested that CD63 expression may be a potential prognostic marker in solid tumors.

Exosomes are small membrane-bound vesicles that are released from various cells into the extracellular spaces $(1,2)$. Such vesicles contain proteins, lipids and nucleic acids, which can be taken up by neighboring or distant cells and subsequently modulate recipient cells $(1,2)$. Recently, it has been reported that exosomes from tumor cells might be involved in tumor progression by modulating the tumor microenvironment, e.g. metastatic niche formation and angiogenesis (3).

The tetraspanin protein CD63 has been described as a key factor in extracellular vesicle production and endosomal cargo sorting, and there have been reports evaluating the association between CD63 expression and tumor existense (4). Moreover, some studies have suggested that CD63 expression is associated with survival in patients with tumors $(3,5-8)$. However, the prognostic value of CD63 expression remains contradictory or inconclusive. Hence, we conducted this meta-analysis to investigate the prognostic value of CD63 expression in solid tumors.

\section{Materials and Methods}

Literature search. We performed a literature search in PubMed, Embase and Cochrane library up to March 15, 2020 using the following terms: (CD63) and (cancer or tumor or carcinoma or neoplasm or malignancy) and (prognostic or predict or prognosis or survival or outcome). All articles were screened for exclusion and review articles were screened to find eligible studies.

Inclusion and exclusion criteria. Inclusion criteria for this study were as follows: (i) CD63 expression analysis was conducted in 


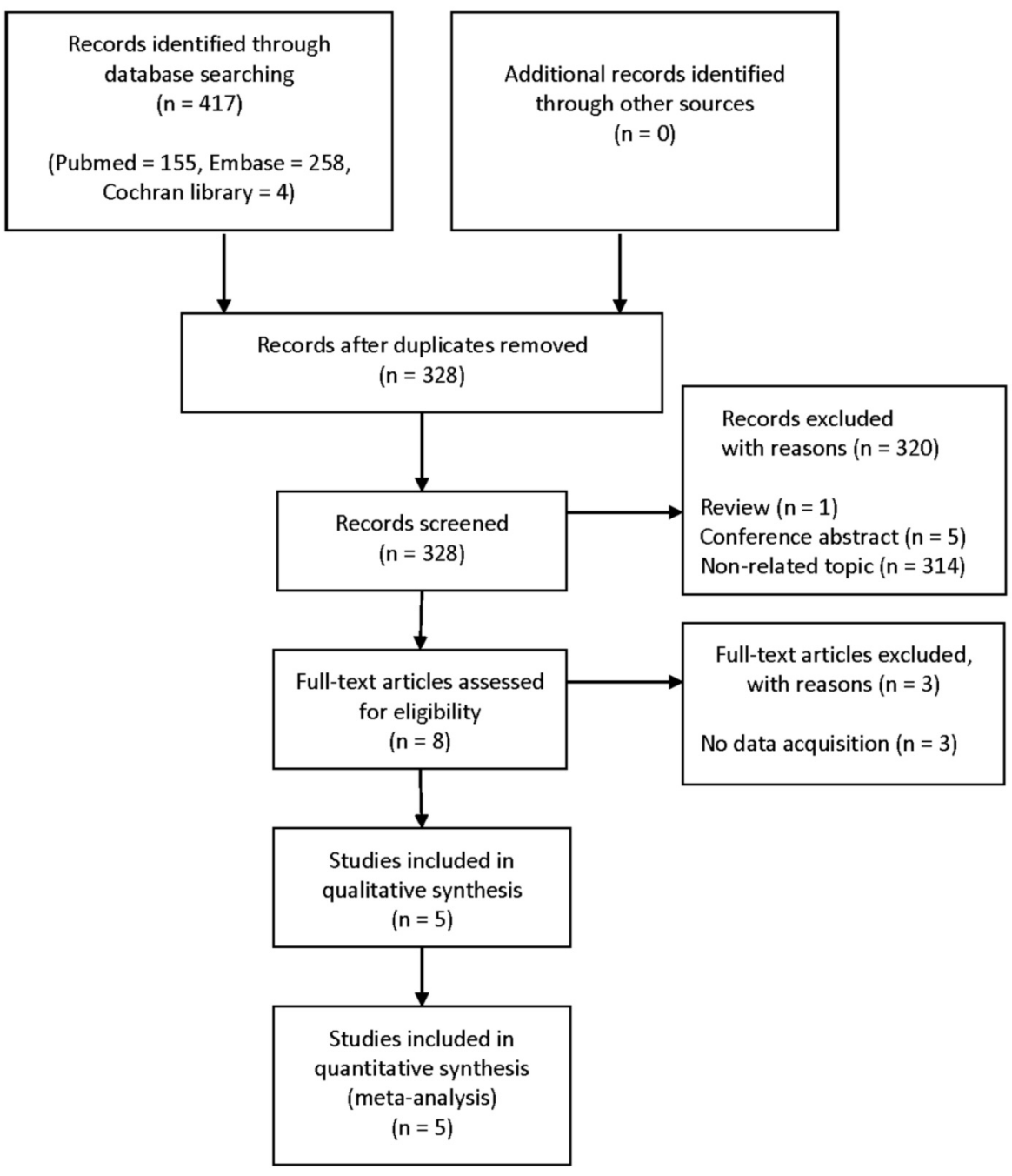

Figure 1. Flow diagram for selection of studies to be included in the meta-analysis.

human tumor tissue, (ii) the association between CD63 expression and survival was evaluated, (iii) the hazard ratio (HR) with $95 \%$ confidence interval (CI) was provided. Exclusion criteria were as follows: (a) duplicate studies, (b) conference abstracts, case reports, reviews, letters, and non-English articles.

Data extraction and quality assessment. Two independent authors collected data from the full texts of included articles. The collected data were as follows: first author, publication year, country, cancer type, sample size, sex and median age of patients, study period, follow-up period, survival outcomes, CD63 expression associated with poor prognosis, cut-off value of CD63 expression, and HR with $95 \%$ CI for survival. Any differences in the data extraction were resolved by consensus.

The quality of included articles was evaluated using the Newcastle-Ottawa Scale (NOS). Article with score greater than 6 was considered as a high quality. Two independent authors performed quality assessment of included articles.
Statistical analysis. All data were analyzed using StataSE12 (Stata, College Station, TX, USA). $p<0.05$ was regarded as statistically significant. Cochran's $Q$ and $I^{2}$ statistics were used to evaluate the heterogeneity among the included articles. HR with 95\% CI was calculated for assessing the prognostic value of CD63 expression in solid tumors. Funnel plot with Egger's test was also performed to reveal the publication bias. And the sensitivity analysis was conducted to explore possible explanations for heterogeneity.

\section{Results}

Study selection and characteristics. A total of 417 studies were reviewed electronically, 320 of which were excluded for the reasons explained in Materials and Methods. Eight full-text articles were assessed for eligibility, and finally five articles were available for this meta-analysis (Figure 1). 
Table I. Basic characteristics of the included studies.

\begin{tabular}{|c|c|c|c|c|c|c|c|c|c|c|c|c|c|}
\hline Study & Country & $\begin{array}{c}\text { Cancer } \\
\text { type }\end{array}$ & $\begin{array}{l}\text { Sample } \\
\text { size }\end{array}$ & $\begin{array}{c}\text { Gender } \\
(\mathrm{M} / \mathrm{F})\end{array}$ & $\begin{array}{l}\text { Mean age } \\
\text { (years) }\end{array}$ & $\begin{array}{l}\text { Study } \\
\text { period }\end{array}$ & $\begin{array}{c}\text { Follow-up } \\
\text { (months) }\end{array}$ & $\begin{array}{l}\text { Survival } \\
\text { outcome }\end{array}$ & $\begin{array}{c}\text { CD63 } \\
\text { detection }\end{array}$ & $\begin{array}{c}\text { CD63 } \\
\text { expression } \\
\text { associated } \\
\text { with poor } \\
\text { prognosis }\end{array}$ & $\begin{array}{l}\text { Cut-off } \\
\text { value of } \\
\text { CD63 } \\
\text { expression }\end{array}$ & $\begin{array}{c}\text { Survival } \\
\text { analysis }\end{array}$ & NOS \\
\hline $\begin{array}{l}\text { Kaprio } \\
\text { et al. } \\
(2020)\end{array}$ & Finland & $\begin{array}{c}\text { Colorectal } \\
\text { cancer and } \\
\text { metastasized } \\
\text { colorectal } \\
\text { cancer }\end{array}$ & 582 & NA & 66.2 & $\begin{array}{l}1990- \\
2001\end{array}$ & $\begin{array}{c}\text { Median } \\
85.2\end{array}$ & DSS & IHC & $\begin{array}{l}\text { Positive } \\
\text { expression }\end{array}$ & $\begin{array}{l}\text { Positive } \\
\text { expression } \\
\text { (low, } \\
\text { moderate } \\
\text { and high) }\end{array}$ & MVA & 8 \\
\hline $\begin{array}{l}\text { Koh et al. } \\
\text { (2019) }\end{array}$ & $\begin{array}{l}\text { South } \\
\text { Korea }\end{array}$ & $\begin{array}{l}\text { Non-small } \\
\text { cell lung } \\
\text { cancer }\end{array}$ & 133 & $111 / 22$ & NA & $\begin{array}{l}2002- \\
2009\end{array}$ & NA & $\begin{array}{l}\text { DSS, } \\
\text { DFS }\end{array}$ & IHC & $\begin{array}{c}\text { Low } \\
\text { expression }\end{array}$ & $\begin{array}{l}\text { Staining } \\
\text { scores with } \\
\text { intensity and } \\
\text { proportion } \\
\quad(<4)\end{array}$ & $\begin{array}{l}\text { UVA } \\
\text { (DSS) } \\
\text { MVA } \\
\text { (DFS) }\end{array}$ & 7 \\
\hline $\begin{array}{l}\text { Miki et al. } \\
\text { (2018) }\end{array}$ & Japan & $\begin{array}{l}\text { Gastric } \\
\text { cancer }\end{array}$ & 595 & $331 / 264$ & NA & NA & NA & OS & IHC & $\begin{array}{l}\text { Positive } \\
\text { expression }\end{array}$ & $\begin{array}{l}\text { Staining } \\
\text { scores with } \\
\text { intensity and } \\
\text { proportion } \\
(\geq 2)\end{array}$ & MVA & 7 \\
\hline $\begin{array}{l}\text { Lewitowicz } \\
\text { et al. }(2016)\end{array}$ & Poland & $\begin{array}{l}\text { Gastro- } \\
\text { intestinal } \\
\text { stromal } \\
\text { tumor }\end{array}$ & 54 & $28 / 26$ & 62.6 & $\begin{array}{l}1998- \\
2015\end{array}$ & $\begin{array}{c}\text { Median } \\
36\end{array}$ & DFS & IHC & $\begin{array}{c}\text { High } \\
\text { expression }\end{array}$ & $\begin{array}{l}\text { Moderate } \\
\text { and strong } \\
\text { expression }\end{array}$ & MVA & 8 \\
\hline $\begin{array}{l}\text { Kwon et al. } \\
\text { (2007) }\end{array}$ & $\begin{array}{l}\text { South } \\
\text { Korea }\end{array}$ & $\begin{array}{c}\text { Lung } \\
\text { adeno- } \\
\text { carcinoma }\end{array}$ & 90 & $67 / 23$ & 62.6 & $\begin{array}{l}1994- \\
2001\end{array}$ & NA & OS & $\mathrm{IHC}$ & $\begin{array}{l}\text { Negative } \\
\text { expression }\end{array}$ & $\begin{array}{l}\text { Negative } \\
\text { expression }\end{array}$ & MVA & 7 \\
\hline
\end{tabular}

DFS, Disease-free survival; DSS, disease-specific survival; IHC, immunohistochemistry; MVA, multivariate analysis; NA, not available; NOS, Newcastle-Ottawa Scale; OS, overall survival, UVA, univariate analysis.

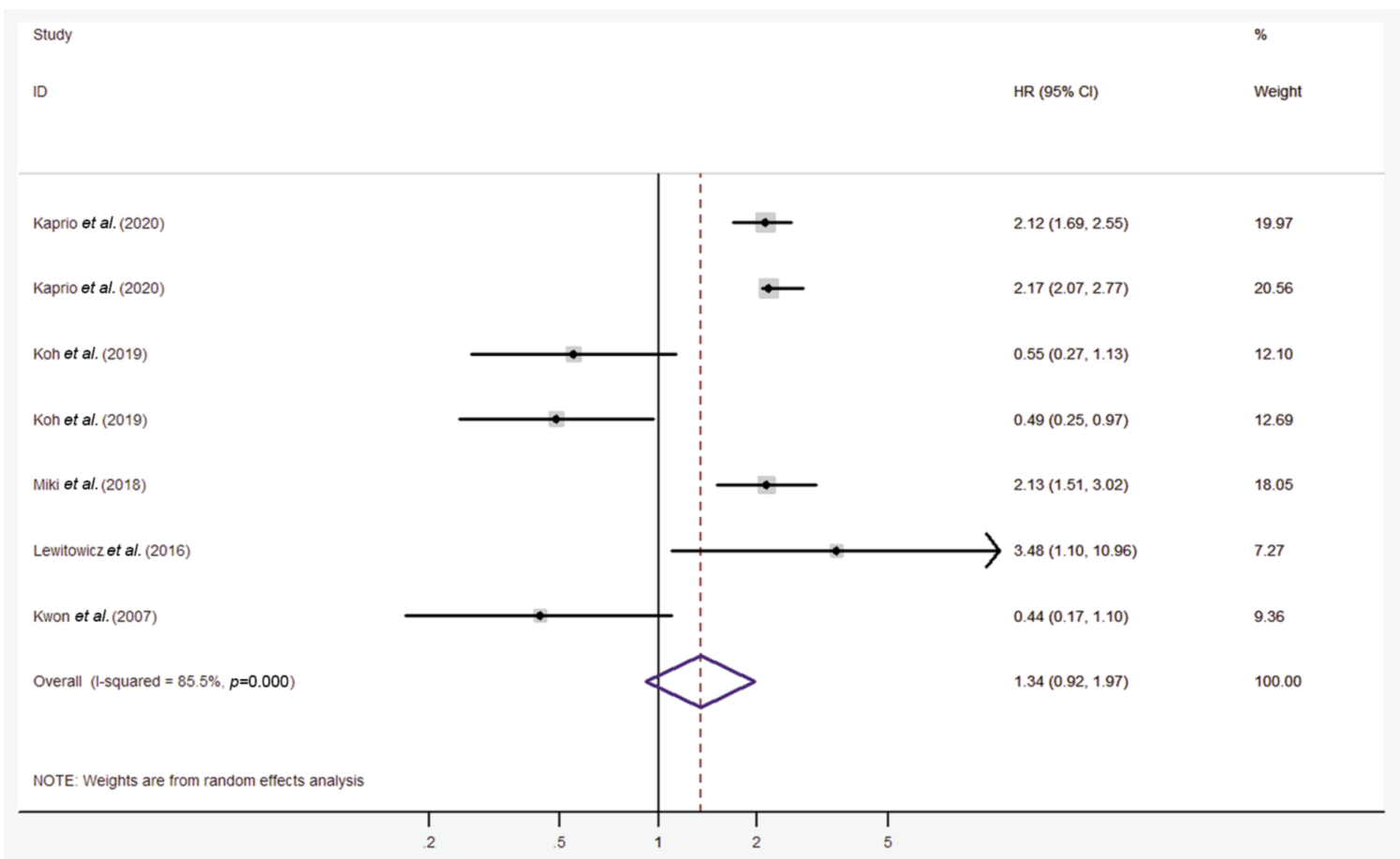

Figure 2. Forest plot of the association between CD63 expression and survival. 
A Study

ID

$\%$

HR $(95 \% \mathrm{Cl}) \quad$ Weight

Others

Kaprio et al. (2020)

Kaprio et al. (2020)

Mikiet al. (2018)

Lewitowicz et al. (2016)

Subtotal (1-squared $=0.0 \%, p=0.872$ )

Lung cancer

Koh et al. (2019)

Koh et al. (2019)

Kwon et al. (2007)

Subtotal (1-squared $=0.0 \%, p=0.921$ )

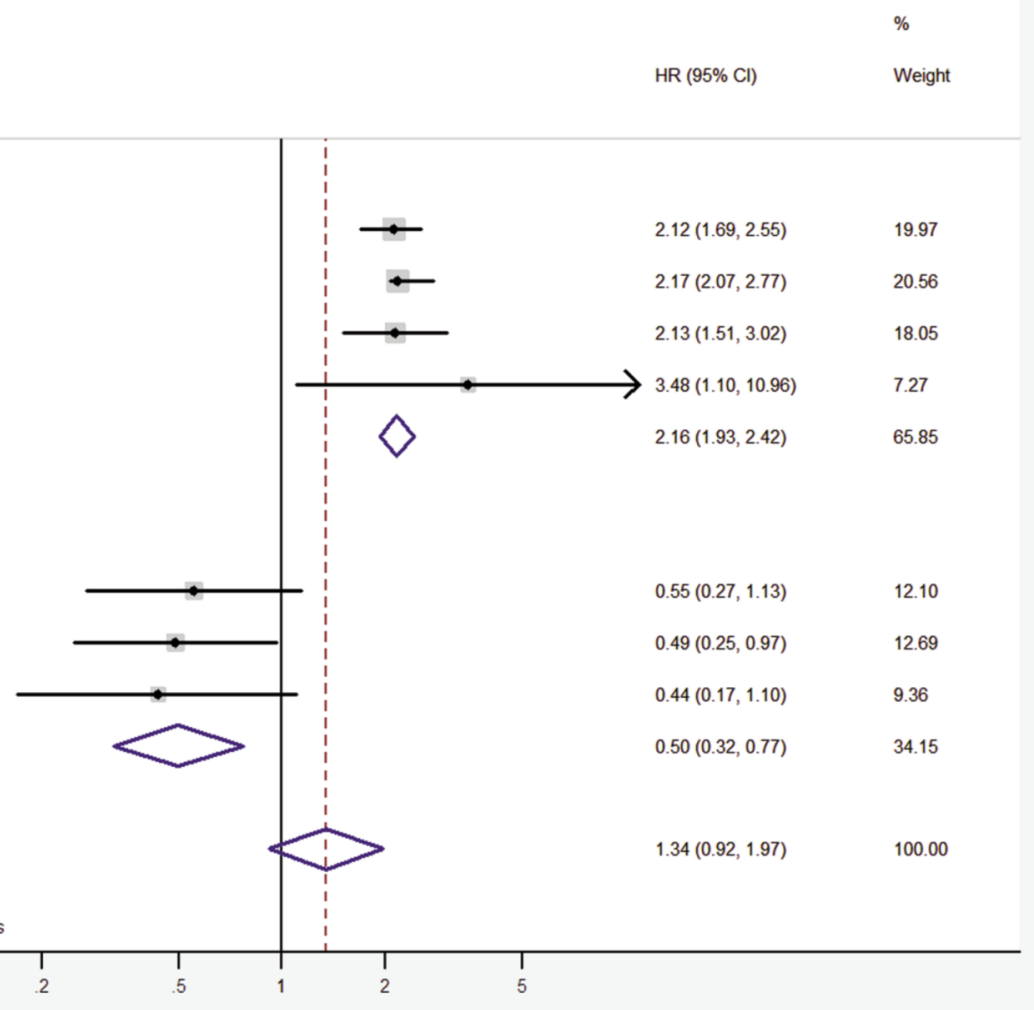

B Study

Overall (I-squared $=85.5 \%, p=0.000$ )

NOTE: Weights are from random effects analysis

ID

tudy

DSS

Kaprio et al. (2020)

Kaprio et al. (2020)

Koh et al. (2019)

Subtotal (I-squared $=85.0 \%, p=0.001$ )

DFS

Koh et al. (2019)

Lewitowicz et al. (2016)

Subtotal (l-squared $=87.9 \%, p=0.004$ )

os

Miki et al. (2018)

Kwon et al. (2007)

Subtotal (l-squared $=89.8 \%, p=0.002$ )

Overall (I-squared $=85.5 \%, p=0.000)$

NOTE: Weights are from random effects analysis

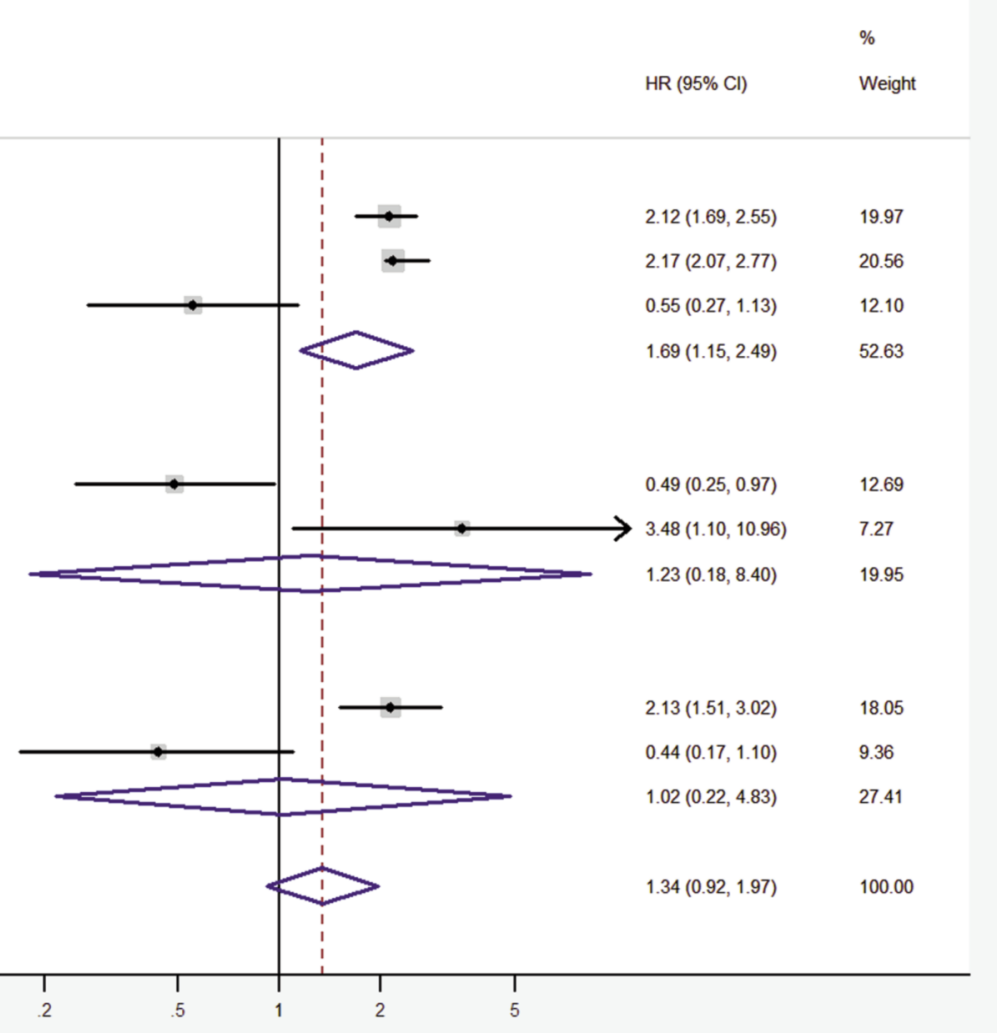

Figure 3. Continued 


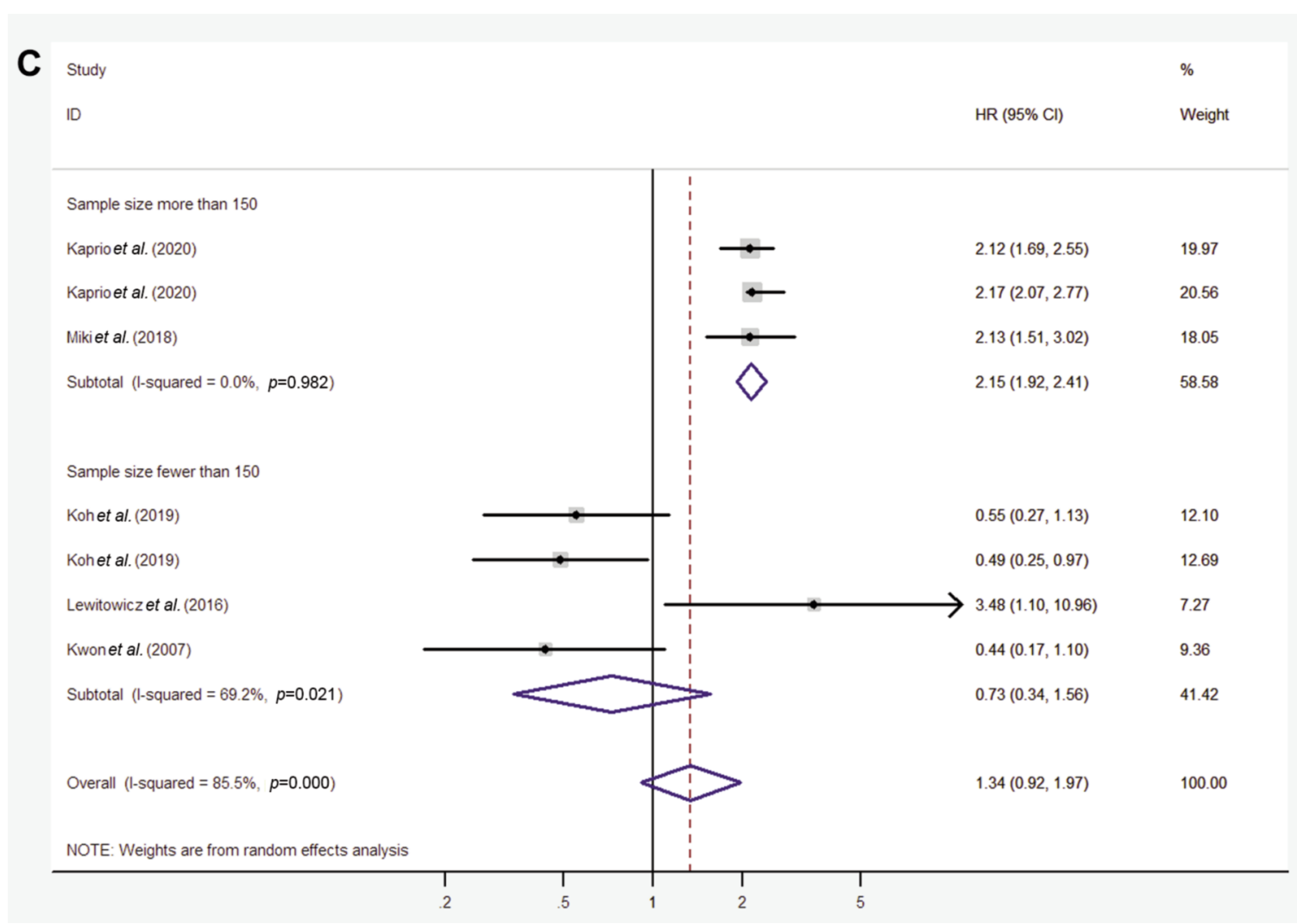

Figure 3. Forest plot for survival stratified by cancer type (A), survival outcome (B) and sample size (C).

The basic characteristics of included studies are summarized in Table I. The included studies consisted of the following cancer types: lung cancer $(n=2)$, colorectal cancer $(n=1)$, gastric cancer $(n=1)$, and gastrointestinal stromal tumor $(n=1)$. Two studies originated from Europe, three from Asia. The total number of patients included in this meta-analysis was 1,454, ranging from 54 to 595 per study. CD63 expression was evaluated by immunohistochemistry in all included studies. The NOS score of included studies was 7 or 8 .

Association between CD63 expression and survival. The heterogeneity among the included studies was assessed using the random-effects model $\left(\mathrm{I}^{2}=85.5 \%, p<0.001\right)$. The HR evaluating CD63 expression on survival was $1.34(95 \%$ $\mathrm{CI}=0.92-1.97, p=0.129$ ) (Figure 2).

When grouped according to tumor type, the HRs of lung cancer and other tumors were 0.50 (95\% CI $=0.32-0.77$, $p=0.002)$ and $2.16(95 \% \mathrm{CI}=1.93-2.42, p<0.001)$ respectively (Figure 3A). Based on the survival outcomes, CD63 expression was significantly associated with poor diseasespecific survival $(\mathrm{HR}=1.69,95 \% \mathrm{CI}=1.15-2.49, p=0.008)$, but not with disease-free survival and overall survival (Figure 3B). On the subgroup analysis of sample size, there was a significant association between CD63 expression with poor survival in the group of sample size more than 150 $(\mathrm{HR}=2.15,95 \% \mathrm{CI}=2.92-2.41, p<0.001)$, but not in the group of sample size with fewer than 150 patients (Figure $3 \mathrm{C}$ ).

Publication bias. As shown in Figure 4A, the Funnel plot showed an asymmetrical bias, but a significant publication bias was not identified (Egger's test, $p=0.075$ ). Therefore, the trim and filled analysis was performed. The analysis revealed that our results were unchanged (Figure 4B).

Sensitivity analysis. As shown in Figure 5, the sensitivity analysis showed that the two studies, by Kaprio et al. and Koh et al., influenced our results. However, our initial results were still significant except for the effects of individual studies through sensitivity analysis, suggesting that our results are reliable $(\mathrm{HR}=1.97,95 \% \mathrm{CI}=1.77-2.20)$.

\section{Discussion}

CD63 is a member of tetraspanins that comprise a large superfamily of cell surface-associated membrane proteins and participate in various cell processes, like cell activation, 

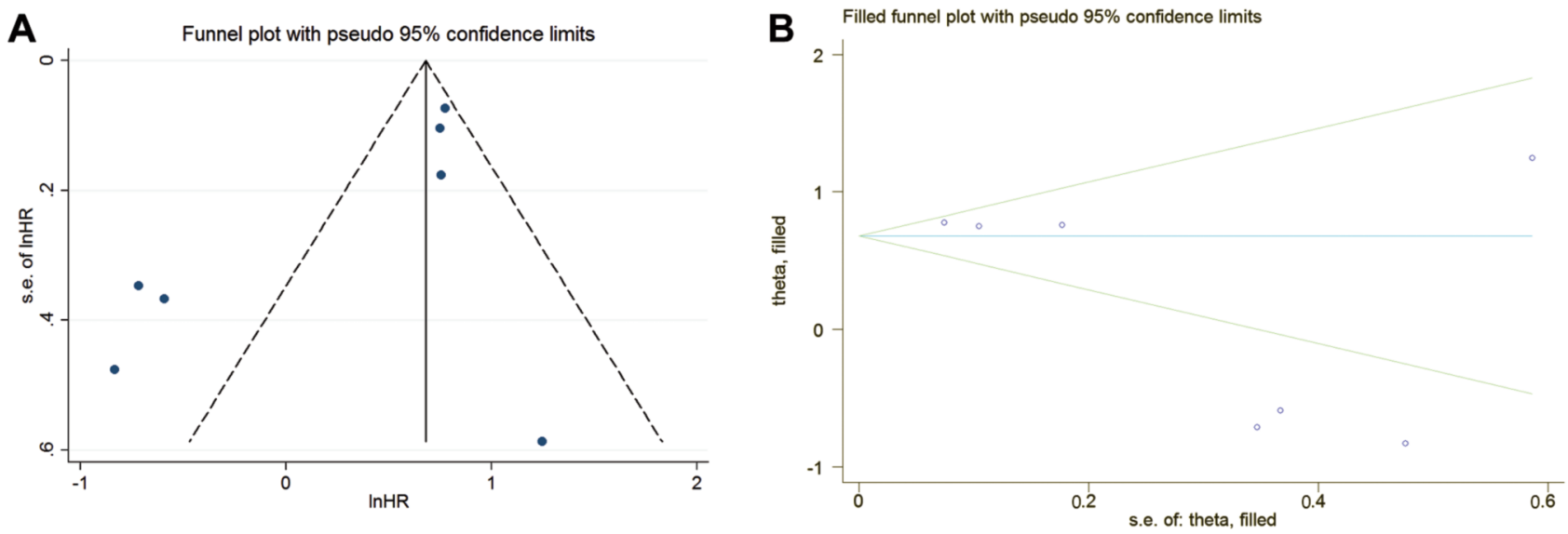

Figure 4. Funnel plot (A) and trim and fill method (B) for publication bias.

adhesion, differentiation, and tumor invasion (9). CD63 was firstly discovered as an abundantly expressed surface antigen in early-stage melanoma cells, and has been described as a tumor suppressor $(9,10)$. CD63 is associated with malignant progression of melanoma, wherein its expression decreases tumor invasion and metastasis by suppression of cellular motility and matrix-degrading ability in melanoma cells (7). A negative relationship between CD63 expression and increased malignancy is reported in various tumors, including ovarian, lung, breast, and colon cancer $(5,7,9,11-13)$.

On the contrary, it has recently become known that CD63 has also been implicated in the regulation of transport of other proteins involved in tumor development, invasiveness and metastasis (9). For example, Rank et al. have shown that CD63 levels are higher in the plasma of ovarian cancer patients compared to those with benign ovarian tumors (14). Moreover, CD63 may execute metastasis-promoting functions as a receptor of tissue inhibitor of metalloproteinases interacting with $\beta 1$ integrins (10). Furthermore, certain studies have revealed that CD63 expression is correlated with a tumor progression and lower survival $(3,6,8,15-17)$. Thus, we performed this meta-analysis to better understand the prognostic value of CD63 expression in solid tumors.

We identified 5 eligible studies with 1,454 patients for this meta-analysis. Kaprio et al., Miki et al. and Lewitowicz at $a l$. reported that positive or high expression of CD63 was associated with poor prognosis in colorectal cancer, gastric cancer and gastrointestinal stromal tumor respectively (3, 6, 8). On the other hand, Kown et al. and Koh et al. showed that negative or low expression of CD63 was correlated with a poor survival in lung adenocarcinoma and non-small cell lung cancer respectively $(5,7)$.

In the present study, we revealed that CD63 expression is associated with prognosis in patients with solid tumors (HR=1.34, 95\% $\mathrm{CI}=0.92-1.97, p=0.129)$. In the subgroup

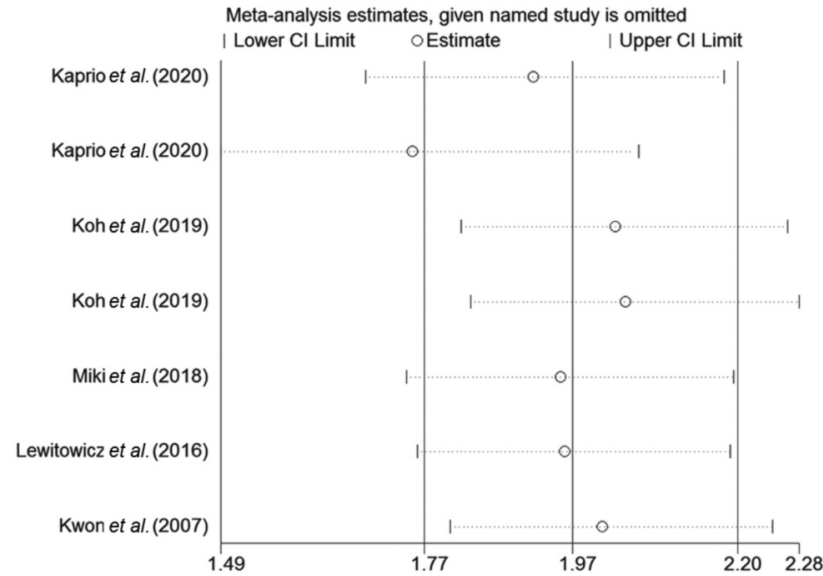

Figure 5. Sensitivity analysis of the association between CD63 expression and survival.

analysis, the HRs of lung cancer and other tumors were 0.50 (95\% CI $=0.32-0.77, p=0.002)$ and $2.16(95 \% \mathrm{CI}=1.93-2.42$, $p<0.001)$ respectively. The results suggested that CD63 expression may have a different effect on each tumor. Further research should reveal the effects of CD63 expression on the type of tumor. CD63 expression was significantly associated with disease-specific survival $(\mathrm{HR}=1.69,95 \% \mathrm{CI}=1.15-2.49, p=0.008)$ and sample size more than $150(\mathrm{HR}=2.15,95 \% \mathrm{CI}=2.92-2.41, p<0.001)$.

There are several limitations in the present study. Our results may be biased because of the small number of studies included. Therefore, further research requires a welldesigned large-scale study. This analysis includes various studies examining the relationship between CD63 expression and prognosis in patients with tumors, so the heterogeneity between the studies cannot be blocked. We hope that future 
studies will analyze the effects of CD63 expression on prognosis according to tumor type.

However, in the present study, we systematically evaluated the association between CD63 expression and prognosis in patients with solid tumors. To the best of our knowledge, this meta-analysis is the first report on the prognostic value of CD63 expression in solid tumors.

In summary, CD63 expression was associated with prognosis and might be a potential prognostic marker in solid tumors.

\section{Conflicts of Interest}

The Authors declare no potential conflicts of interest.

\section{Authors' Contributions}

H.M. Koh and D.C. Kim designed this review; H.M. Koh and B.G. Jang searched the databases and inspected all candidate articles; H.M. Koh and D.C. Kim extracted data and analyzed the data; H.M. Koh and B.G. Jang assessed the quality of included studies by the NOS; H.M. Koh wrote the manuscript, and all authors reviewed the manuscript.

\section{Acknowledgements}

The Authors received no financial support for the research.

\section{References}

1 Nakamura K, Jinnin M, Harada M, Kudo H, Nakayama W, Inoue K, Ogata A, Kajihara I, Fukushima S and Ihn H: Altered expression of CD63 and exosomes in scleroderma dermal fibroblasts. J Dermatol Sci 84: 30-39, 2016. PMID: 27443953. DOI: 10.1016/j.jdermsci.2016.06.013

2 Zhang J, Li S, Li L, Li M, Guo C, Yao J and Mi S: Exosome and exosomal microRNA: trafficking, sorting, and function. Genomics Proteomics Bioinformatics 13: 17-24, 2015. PMID: 25724326. DOI: 10.1016/j.gpb.2015.02.001

3 Miki Y, Yashiro M, Okuno T, Kuroda K, Togano S, Hirakawa K and Ohira M: Clinico-pathological significance of exosome marker CD63 expression on cancer cells and stromal cells in gastric cancer. PLoS One 13: e0202956, 2018. PMID: 30222750 DOI: 10.1371/journal.pone.0202956

4 Hurwitz SN, Cheerathodi MR, Nkosi D, York SB andMeckes DG, Jr.: Tetraspanin CD63 bridges autophagic and endosomal processes to regulate exosomal secretion and intracellular signaling of epstein-barr virus LMP1. J Virol 92(5): e01969-17, 2018. PMID: 29212935. DOI: 10.1128/JVI.01969-17

5 Kwon MS, Shin S, Yim S, Lee KY, Kang H, Kim T and Chung $\mathrm{Y}$ : CD63 as a biomarker for predicting the clinical outcomes in adenocarcinoma of lung. Lung Cancer 57: 46-53, 2007. PMID: 17350713. DOI: 10.1016/j.lungcan.2007.01.032

6 Kaprio T, Hagstrom J, Andersson LC and Haglund C: Tetraspanin CD63 independently predicts poor prognosis in colorectal cancer. Histol Histopathol 19: 18209, 2020. PMID: 32073129. DOI: $10.14670 / \mathrm{HH}-18-209$
7 Koh H, An H, Jung J and Song D: The prognostic significance of CD63 expressionin patients with non-small cell lung cancer. Pol J Pathol 70: 183-188, 2019. PMID: 31820861. DOI: 10.5114/pjp.2019.90394

8 Lewitowicz P, Matykiewicz J, Koziel D, Chrapek M, HoreckaLewitowicz A and Gluszek S: CD63 and GLUT-1 overexpression could predict a poor clinical outcome in GIST: a study of 54 cases with follow-up. Gastroenterol Res Pract 2016: 648374, 2016. PMID: 27795705. DOI: 10.1155/2016/6478374

9 Pols MS and Klumperman J: Trafficking and function of the tetraspanin CD63. Exp Cell Res 315: 1584-1592, 2009. PMID: 18930046. DOI: 10.1016/j.yexcr.2008.09.020

10 Seubert B, Cui H, Simonavicius N, Honert K, Schafer S, Reuning U, Heikenwalder M, Mari B and Kruger A: Tetraspanin CD 63 acts as a pro-metastatic factor via $\beta$-catenin stabilization. Int J Cancer 136: 2304-2315, 2015. PMID: 25354204. DOI: 10.1002/ijc. 29296

11 Sordat I, Decraene C, Silvestre T, Petermann O, Auffray C, Piétu Gand Sordat B: Complementary DNA arrays identify CD63 tetraspanin and $\alpha 3$ integrin chain as differentially expressed in low and high metastatic human colon carcinoma cells. Lab Invest 82: 1715, 2002. PMID: 12480921. DOI: 10.1097/ 01.lab.0000044350.18215.0d

12 Sauer G, Kurzeder C, Grundmann R, Kreienberg R, Zeillinger $\mathrm{R}$ and Deissler H: Expression of tetraspanin adaptor proteins below defined threshold values is associated with in vitro invasiveness of mammary carcinoma cells. Oncol Rep 10: 405410, 2003. PMID: 12579280 .

13 Zhijun X, Shulan Z and Zhuo Z: Expression and significance of the protein and mRNA of metastasis suppressor gene ME491/CD63 and integrin alpha5 in ovarian cancer tissues. Eur J Gynaecol Oncol 28: 179-183, 2007. PMID: 17624082.

14 Rank A, Libhardt S, Zwirner J, Burges A, Nieuwland R and Toth B: Circulating microparticles in patients with benign and malignant ovarian tumors. Anticancer Res 32(5): 2009-14, 2012. PMID: 22593480.

15 Cui H, Seubert B, Stahl E, Dietz H, Reuning U, Moreno-Leon L, Ilie M, Nagase H, Mari B and Kruger A: Tissue inhibitor of metalloproteinases-1 induces a pro-tumourigenic increase of miR-210 in lung adenocarcinoma cells and their exosomes. Oncogene 34: 3640, 2015. PMID: 25263437. DOI: 10.1038/ onc. 2014.300

16 Rorive S, Lopez XM, Maris C, Trepant A, Sauvage S, Sadeghi N, Roland I, Decaestecker C and Salmon I: TIMP-4 and CD63: new prognostic biomarkers in human astrocytomas. Mod Pathol 23: 1418, 2010. PMID: 20693981. DOI: 10.1038/modpathol. 2010.136

17 Toricelli M, Melo FH, Hunger A, Zanatta D, Strauss BE and Jasiulionis MG: Timp1 promotes cell survival by activating the PDK1 signaling pathway in melanoma. Cancers (Basel) 9: 37, 2017. PMID: 28430130. DOI: 10.3390/cancers 9040037 